\title{
Low or undetectable TPO receptor expression in malignant tissue and cell lines derived from breast, lung, and ovarian tumors
}

\author{
Connie L Erickson-Miller ${ }^{1 *}$, Kodandaram Pillarisetti ${ }^{1}$, Jennifer Kirchner ${ }^{1}$, David J Figueroa ${ }^{1}$, Lone Ottesen ${ }^{2}$, \\ Anne-Marie Martin', Yuan Liu', Yasser Mostafa Kamel ${ }^{2}$ and Conrad Messam
}

\begin{abstract}
Background: Numerous efficacious chemotherapy regimens may cause thrombocytopenia. Thrombopoietin receptor (TPO-R) agonists, such as eltrombopag, represent a novel approach for the treatment of chemotherapy-induced thrombocytopenia. The TPO-R MPL is expressed on megakaryocytes and megakaryocyte precursors, although little is known about its expression on other tissues.

Methods: Breast, lung, and ovarian tumor samples were analyzed for MPL expression by microarray and/or quantitative reverse transcription-polymerase chain reaction (qRT-PCR), and for TPO-R protein expression by immunohistochemistry $(\mathrm{IHC})$. Cell line proliferation assays were used to analyze the in vitro effect of eltrombopag on breast, lung, and ovarian tumor cell proliferation. The lung carcinoma cell lines were also analyzed for TPO-R protein expression by Western blot.

Results: MPL mRNA was not detectable in 118 breast tumors and was detectable at only very low levels in $48 \%$ of 29 lung tumors studied by microarray analysis. By qRT-PCR, low but detectable levels of MPL MRNA were detectable in some normal (14-43\%) and malignant (3-17\%) breast, lung, and ovarian tissues. A comparison of MPL to EPOR, ERBB2, and IGFIR mRNA demonstrates that MPL mRNA levels were far lower than those of EPOR and ERBB2 mRNA in the same tissues. IHC analysis showed negligible TPO-R protein expression in tumor tissues, confirming mRNA analysis. Culture of breast, lung, and ovarian carcinoma cell lines showed no increase, and in fact, showed a decrease in proliferation following incubation with eltrombopag. Western blot analyses revealed no detectable TPO-R protein expression in the lung carcinoma cell lines.

Conclusions: Multiple analyses of breast, lung, and ovarian tumor samples and/or cell lines show no evidence of MPL mRNA or TPO-R protein expression. Eltrombopag does not stimulate growth of breast, lung, or ovarian tumor cell lines at doses likely to exert their actions on megakaryocytes and megakaryocyte precursors.
\end{abstract}

\section{Background}

Breast cancer is the most commonly occurring neoplasm and the second leading cause of cancer deaths in women. Lung cancer is the second most frequent cancer diagnosis in men and women, and remains the leading cause of cancer deaths. Although ovarian cancer affects fewer women than breast or lung cancer, it is one of the most lethal types of cancer [1]. Current clinical guidelines recommend platinum-containing chemotherapy regimens,

\footnotetext{
* Correspondence: connie.l.erickson-miller@gsk.com

'GlaxoSmithKline, 1250 South Collegeville Rd, Collegeville, PA 19426, USA

Full list of author information is available at the end of the article
}

among others, for these malignancies in different disease stages [2-7]. Established treatment protocols may be associated with a range of adverse events (AEs), including thrombocytopenia, anemia, and neutropenia. Newer chemotherapy combinations including carboplatin plus pemetrexed or gemcitabine in non-small cell lung cancer (NSCLC) may also be associated with high rates of thrombocytopenia [8].

Thrombocytopenia may lead to significant clinical consequences including petechiae, gastrointestinal bleeding, and bleeding into the brain [9]. Neutropenia, anemia, or thrombocytopenia resulting from bone marrow suppression can delay chemotherapy administration and/or may

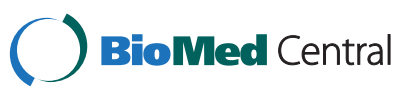


prompt dose reductions, with possible negative impact on disease control [10]. The use of hematopoietic growth factors has ameliorated this problem to some degree with respect to red and white blood cell production $[11,12]$. However, there are concerns that some growth factors could induce proliferation of other cell types, including tumor cells $[13,14]$.

Thrombopoietin (TPO) is a critical cytokine regulating thrombopoiesis. It is the endogenous ligand for the thrombopoietin receptor (TPO-R) MPL expressed on the surface of megakaryocytes, megakaryocyte precursors, and platelets [15-18]. TPO-R agonists are approved for the treatment of chronic immune thrombocytopenia (ITP). The interaction of the selective, nonpeptidyl TPO-R agonist, eltrombopag, with TPO-R triggers activation of the JAK-STAT and MAP kinase, but not the AKT, signal transduction pathways. This causes alterations in gene expression patterns to promote megakaryocytic differentiation and maturation, resulting in increased platelet counts $[19,20]$. There are differences between the amplitude and extent of signaling between TPO and eltrombopag [21]. Acute myeloid leukemia (AML) blasts have been shown to express TPO-R [22] and in some reports TPO has induced proliferation of these blasts [23], although investigations in leukemia cell lines show conflicting results [24,25]. A variety of human nonmegakaryocytic leukemia and lymphoma cell lines show decreased, rather than increased, proliferation upon incubation with eltrombopag [26]. In vitro and in vivo analyses of bone marrow mononuclear cells from patients with AML and myelodysplastic syndromes (MDS) similarly showed no increase in proliferation with eltrombopag treatment [25,27].

The objective of this study was to determine whether solid tumors (i.e., breast, lung, and ovarian) express $M P L$ mRNA or TPO-R protein, and whether eltrombopag affects the proliferation of solid tumor cell lines. Expression of $M P L$ mRNA was assessed by microarray analysis in breast and lung tumor samples and by quantitative reverse transcription-polymerase chain reaction (qRT-PCR) in normal and malignant tissue samples from breast, lung, and ovary. TPO-R protein expression was determined by immunohistochemistry (IHC) on breast, lung, and ovarian tumor samples and by western blot on lung cell lines. Cell proliferation in response to eltrombopag was evaluated in breast, lung, and ovarian cancer cell lines.

\section{Methods}

\section{Patient samples}

In accordance with the Helsinki Declaration, all patients provided written informed consent for use of their samples, and the collection and use of the samples received Institutional Review Board (IRB) approval.

\section{Microarray analysis}

\section{Experimental samples}

Archival tissue samples from 118 patients who had locally advanced or metastatic breast cancer and had failed treatment with anthracycline-, taxane-, and trastuzumabcontaining regimens were studied. Specimens were obtained from patients who had histologically confirmed invasive breast cancer with Stage IIIB, Stage IIIC with T4 lesion, or Stage IV disease (GSK Study EGF100151), with documentation of ERBB2 overexpression (IHC $3+$ or IHC $2+$ with fluorescence in situ hybridization [FISH] confirmation) [28,29]. Microarray analysis was performed at Response Genetics, Inc (Los Angeles, CA, USA).

Frozen tissue samples from 29 patients who were presurgical, treatment-naive, with Stage IA or Stage IB, resectable NSCLC were studied (GSK Study VEG105290). Microarray analysis was performed at Weill Medical College of Cornell University (New York, NY, USA).

\section{Experimental protocol}

Archival breast tumor specimens were formalin-fixed and embedded in paraffin. The quality of tumor tissue RNA extraction was assessed by laser capture microdissection. Reverse transcription-polymerase chain reaction (RT-PCR) for 300 base pair (bp) of the $\beta$-actin gene was used for quality control of these samples. Samples with a cycle time $(\mathrm{CT})$ of $<32$ at the $300 \mathrm{bp}$ level were acceptable for microarray analysis. mRNA and cDNA were prepared from archival breast tumor tissues and frozen NSCLC samples using the Affymetrix HG-U133 Plus2 array (Affymetrix, Inc., Santa Clara, CA, USA). RNA microarray gene signal intensity was normalized using the robust microchip analysis (RMA) method described by Irizarry et al [30]. Samples with $\mathrm{RMA}<50$ are below the level of detection by this method.

\section{qRT-PCR analysis}

\section{Experimental samples}

Samples of normal tissue cDNA and tumor tissue cDNA were obtained from Cytomyx (Lexington, MA, USA). Seven samples of normal breast tissue were studied, and 41 breast carcinoma samples, including tissue from cancers of Stage I, Stage II, and Stage IIIB were analyzed. Eight normal lung specimens and lung tissue samples from 40 tumors, ranging from Stages IA to IV were examined. Ovarian samples included 7 normal ovarian tissues and 41 ovarian tumors ranging from Stages I to IV.

\section{Experimental protocol}

$M P L$ gene expression was measured using FAM-TAMRAlabeled primers and probes in a 7900HT thermal cycler using a standard 40-cycle profile with 9600 emulation. Following amplification, calculations were performed to determine the relative abundance of MPL normalized to 
3 housekeeping genes, glyceraldehyde-3-phosphate dehydrogenase $(G A P D H), \beta$-actin $(A C T B)$, and cyclophilin A (PPIA). Each result is presented as a normalized value of mRNA. EPOR, ERBB2, and IGF1R were also assessed to provide data for comparable receptors. Primers and probes were custom made by Integrated DNA Technologies (Coralville, IA, USA). Sequences for the primers and probes were previously described [31] and are listed in Additional file 1: Table S1.

\section{qRT-PCR data analysis}

$\mathrm{CT}$ values for genes of interest were normalized to the internal housekeeping genes run in the reaction using in-house software. Raw abundance value was calculated using the following equation: Abundance $=10 \mathrm{e}[(40-\mathrm{CT}) /$ 3.35]. Samples were scaled relative to each other using the geometric mean of the set of valid housekeeping gene data points for that sample. Each data point was then expressed as the ratio of the housekeeping gene abundance in the sample to the average of that housekeeping gene in all samples and marked invalid if it had statistically inconsistent behavior with the other housekeeping genes in those samples of similar tissue types. Samples with a relative abundance of $<50$ are below the level of detection of this method.

\section{IHC for TPO-R protein expression Experimental samples}

Formalin-fixed, paraffin embedded (FFPE) controls and FFPE specimens of breast, lung, and ovarian cancer were procured by Mosaic Laboratories under an IRB-reviewed protocol that allows for use of remnant, de-identified, or anonymized human samples for in vitro analysis under the guidelines defining Exemption from Human Subject Research as defined by the Office of Human Research Protection. FFPE tissue samples of breast, lung, and ovarian cancer were also procured from OriGene (formerly Cytomyx) for analysis. A FFPE block of N2C-Tpo cells, a Tpo-dependent megakaryocytic leukemia cell line, and of normal bone marrow were used as positive controls for TPO-R expression.

\section{Experimental protocol}

Immunohistochemical analysis was performed in accordance with Mosaic Laboratories' Standard Operating Procedures. Briefly, the procedure was performed manually using the Envision ${ }^{\mathrm{TN}}$ system and ancillary reagents (Dako, Carpinteria, CA). Specimens were sectioned at a thickness of 4 microns, mounted onto positive-charged glass slides, dried, deparaffinized, and rehydrated. Following rehydration, tissue sections were incubated in Envision peroxidase for 5 minutes to quench endogenous peroxidase. Heat-induced epitope retrieval was performed using Rip Tide buffer for 40 minutes at $95^{\circ} \mathrm{C}$. Slides were incubated with anti-CD110 antibody (clone 1.78.1) (BD Biosciences) diluted in diluent (Dako) for 30 minutes. Slides were then rinsed twice in Splash-T buffer for 5 minutes each. Signal was visualized using Envision + Mouse HRP detection reagent (Dako) for 30 minutes, followed by 3,3 diamino benzidine according to manufacturer's instructions. Slides were rinsed with water, counterstained with hematoxylin (Dako), dehydrated through graded alcohols, cleared in xylene, and coverslipped for microscopic evaluation.

\section{Data analysis}

Staining was evaluated by a pathologist; evaluation of reactivity involved a combination of the following: cellular localization of staining, staining intensity, subcellular localization, and percentage of cells staining in the primary component of the tissue type of interest. The CD110 IHC assay was scored on a semi-quantitative scale, and the percentage of cancer cells staining at each of the following 4 levels was recorded: 0 (unstained), 1+ (weak staining), 2+ (moderate staining), and 3+ (strong staining). An H-score was calculated based on the summation of the product of percent of cells stained at each intensity, using the following equation: $(3 \times \%$ cells staining at $3+)+(2 \times \%$ cells staining at $2+)+(1 \times \%$ cells staining at $1+$ ). $\mathrm{H}$-score values range from $0-300$. (Additional file 2: Table S2).

\section{Cell line proliferation assays Experimental preparations}

Cell lines were obtained from the American Type Culture Collection (Walkersville, MD, USA). All cells were maintained in log-phase growth in their respective media. The breast cancer cell lines (MCF-7, BT474, and HCC1937), lung cancer cell lines (A549, NCI-H226, NCI-H460, and NCI-H510), and ovarian cell lines (OVCAR4 and SKOV-3) were grown in RPMI 1640 medium with $10 \%$ fetal calf serum (FCS). The ovarian carcinoma cell line OVCAR3 was grown in RPMI 1640 medium with 20\% FCS, $1 \%$ sodium pyruvate, and $1 \% \mathrm{v} / \mathrm{v}$ glutamine.

All experiments were performed with milled, monoethanolamine salt form SB-497115-GR (eltrombopag) resuspended in water to $10 \mathrm{mg} / \mathrm{mL}$, and diluted in Iscove's Modified Dulbecco's Medium (IMDM) with 1\% FCS. Recombinant human TPO (rhTPO) was purchased from R\&D Systems (Minneapolis, MN, USA) and diluted in IMDM.

\section{Experimental protocols}

Cells for the Cell Titer $\mathrm{Glo}^{\circledR}$ assay were plated at $1 \times 10^{3}$ cells/well in 96-well plates in medium containing $10 \%$ FCS and allowed to adhere for 24 hours. Cells were treated with eltrombopag at $0,0.1,0.4,1,4,10$, and $40 \mu \mathrm{g} / \mathrm{mL}$. In breast and ovarian cancer cell lines, eltrombopag was 
also tested at $100 \mu \mathrm{g} / \mathrm{mL}$. rhTPO at $100 \mathrm{ng} / \mathrm{mL}$ was also tested in these experiments. Cells were incubated for 72 hours at $37^{\circ} \mathrm{C}$ in $5 \% \mathrm{CO}_{2}$ after the addition of eltrombopag or rhTPO. Active cell determinations were performed using the Cell Titer $\mathrm{Glo}^{\circledR}$ reagent (Promega, Madison, WI, USA) according to the manufacturer's protocol. Results were reported as relative luminescence units (RLU).

\section{Data analysis}

The calculated mean and standard deviations were produced using triplicate samples for each experiment. The $\mathrm{IC}_{50}$ was determined using XLfit version 4.2.1, utilizing the best fit model for each data set.

\section{Western blotting for TPO-R protein expression Experimental preparations}

Lung cancer cell lines, A549, NCI-H226, NCI-H460, and NCI-H510, were grown as described above.

\section{Experimental protocol}

Western blots for TPO-R protein expression were performed on reduced cell lysates of log-phase growth lung cancer cell lines $(50 \mu \mathrm{g} /$ well $)$ on a NuPage $4-12 \%$ BisTris gel (Invitrogen, Carlsbad, CA, USA) with MOPS running buffer. Precision Protein Dual Color Standards (Bio-Rad, Hercules, CA, USA) were used. The gels were transferred to nitrocellulose and stained with a rabbit polyclonal anti-TPO-R primary antibody (Upstate Biotechnology Inc., Lake Placid, NY, USA; Cat\# 06-944) and analyzed with an Odyssey ${ }^{\circledR}$ infrared imager (LI-COR Biosciences, Lincoln, NE, USA).

\section{Results and discussion}

\section{MPL expression by microarray analysis}

None of the 118 advanced or metastatic breast cancer samples expressed detectable levels of $M P L$ mRNA; all samples had RMA $<50$. EPOR mRNA was expressed at detectable levels in 89/118 (75\%); all 118 (100\%) demonstrated detectable levels of ERBB2 mRNA; and 102/118 (86\%) expressed detectable levels of IGF1R mRNA (Table 1, Figure 1). ERBB2 mRNA was expressed at the highest level compared with $M P L, E P O R$, and IGF1R mRNA levels.

Of the 29 samples of NSCLC studied by microarray, 14 (48\%) expressed low but detectable levels of $M P L$ mRNA (Table 1, Figure 1). All 29 samples (100\%) expressed EPOR mRNA; 28 of 29 (97\%) expressed ERBB2 mRNA, and all 29 (100\%) expressed IGF1R mRNA.

\section{MPL expression by qRT-PCR analysis}

A more accurate quantitation of $M P L$ expression was undertaken using qRT-PCR. MPL expression was lower in both normal and malignant breast tissue than
Table 1 Expression of detectable levels of MPL, EPOR, ERBB2, and IGF1R MRNA in primary tumors of breast and NSCLC origin by microarray analysis

\begin{tabular}{lcc}
\hline & Breast $\mathbf{N}=\mathbf{1 1 8} \mathbf{n}(\%)$ & NSCLC $\mathbf{N}=\mathbf{2 9} \mathbf{n}(\%)$ \\
\hline MPL & $0(0)$ & $14(48)$ \\
\hline$E P O R$ & $89(75)$ & $29(100)$ \\
\hline$E R B B 2$ & $118(100)$ & $28(97)$ \\
\hline IGFIR & $102(86)$ & $29(100)$
\end{tabular}

NSCLC, non-small cell lung cancer. Data are represented as number of tumors with detectable (RMA $\geq 50$ ) expression and percent of tumor type with detectable expression in parenthesis.

expression of EPOR, ERBB2, and IGF1R (Table 2, Figures $2 \mathrm{~A}$ and $3 \mathrm{~A})$. One of 7 (14\%) normal breast tissue samples studied and 1/40 (3\%) breast tumor samples demonstrated detectable $M P L$ mRNA expression (Table 2, Figures 2A and 3A). EPOR mRNA expression was observed in $7 / 7$ (100\%) normal breast samples, and in $32 / 40(80 \%)$ breast cancer samples. Four of 7 (57\%) normal breast tissue samples and 33/40 (83\%) breast tumor samples demonstrated detectable ERBB2 expression. IGF1R expression was detected in 2/7 (29\%) normal breast tissue samples and in 15/40 (38\%) breast cancer samples.

Detectable $M P L$ expression was observed using qRTPCR in 1/8 (13\%) normal lung tissue samples, and in $1 / 40$ (3\%) lung tumor samples. The level of MPL expression was equivalent in the normal lung tissue and in the positive tumor sample (Table 2, Figures $2 \mathrm{~B}$ and $3 \mathrm{~B}$ ). The lung tumor sample that expressed detectable $M P L$ mRNA also expressed EPOR mRNA at levels greater than did other lung tumor samples. EPOR mRNA expression was identified in all $8(100 \%)$ normal lung samples, and in 28/40 (70\%) lung tumor samples studied. ERBB2 mRNA expression was detected in all $8(100 \%)$ normal samples and in 22/40 (55\%) lung tumor samples. In contrast, IGF1R mRNA expression was identified at detectable levels in only $1 / 8$ (13\%) normal lung samples and 2/40 (5\%) lung tumor samples studied (Table 2, Figures $2 \mathrm{~B}$ and $3 \mathrm{~B})$.

Three of 7 (43\%) normal ovarian tissue samples expressed detectable MPL mRNA and 3/41 (7 \%) ovarian tumor samples had detectable $M P L$ mRNA. Relative expression of $M P L$ was similar or greater in the positive normal ovary and ovarian tumor samples (Table 2, Figures $2 \mathrm{C}$ and $3 \mathrm{C}$ ). All 7 (100\%) normal ovary samples and all 41 (100\%) ovarian tumors studied expressed $E P O R$ mRNA. ERBB2 expression was also observed in all 7 (100\%) normal samples and in 39/41 (95\%) tumor samples. IGF1R expression was not detected in the 7 normal ovarian samples, and was detectable in $7 / 41$ (17\%) ovarian tumors studied. Expression of $M P L$ and IGF1R mRNA was low compared with EPOR and ERBB2 mRNA levels in normal ovary and ovarian tumor samples 


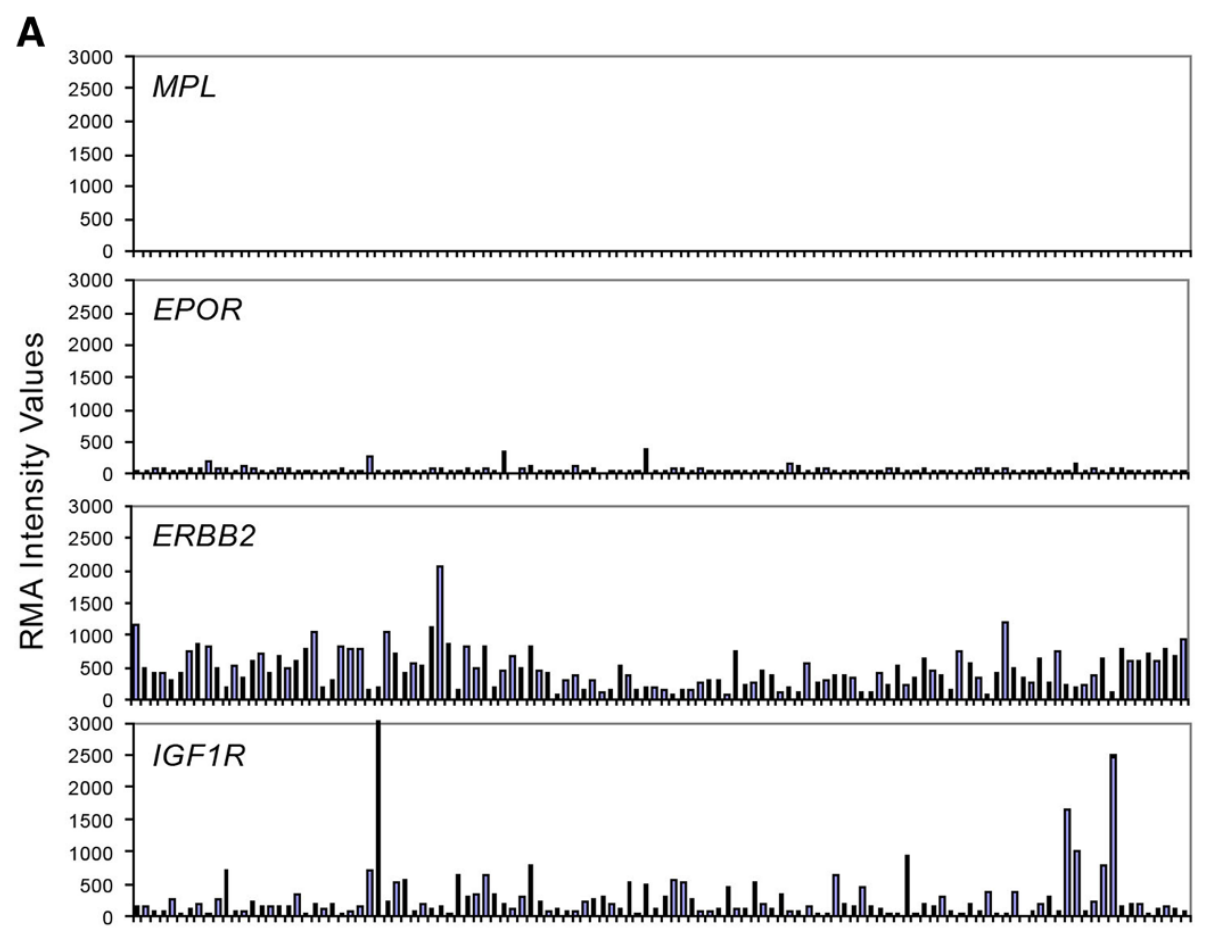

B
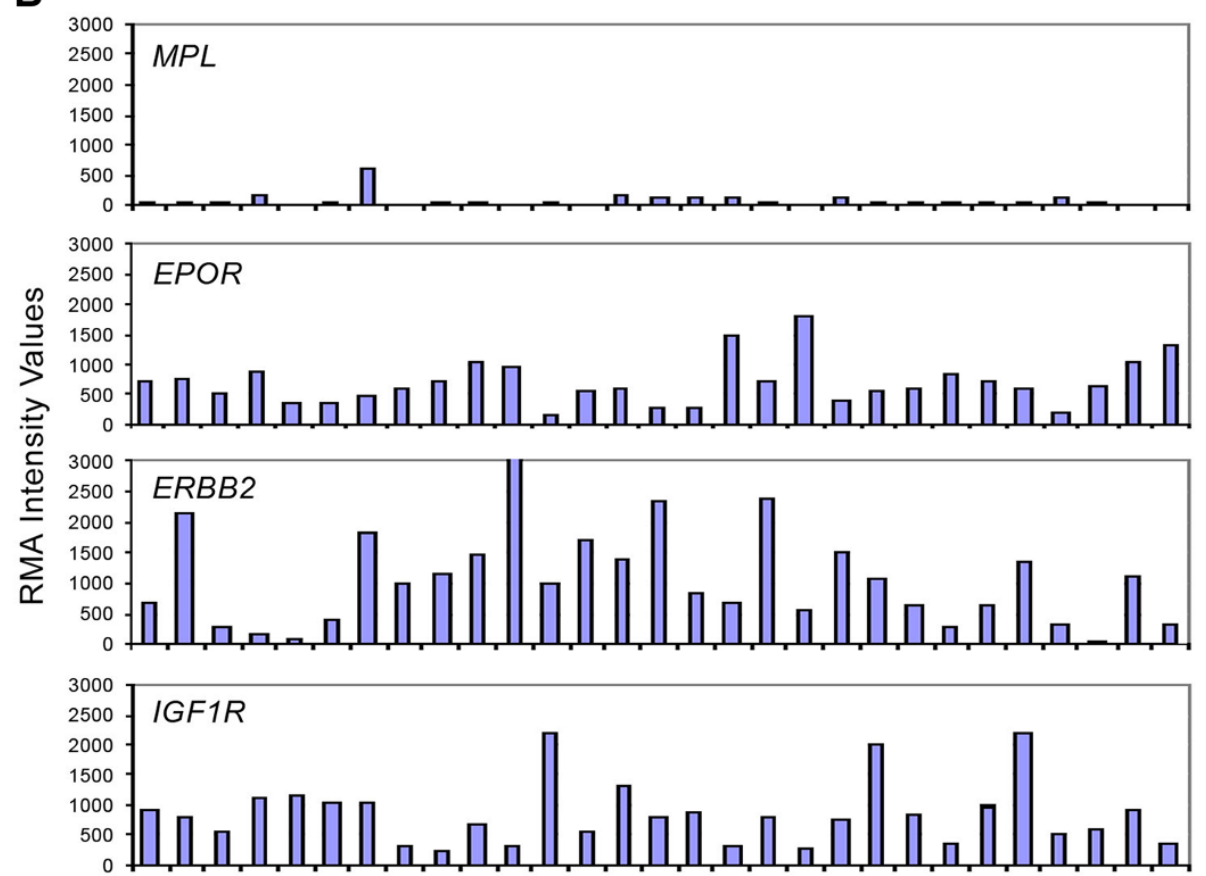

Figure 1 Expression of MPL mRNA message determined by microarray analysis, compared to EPOR, ERBB2, and IGF1R message levels in (A) 118 breast cancer tumor samples (Study EGF100151) and (B) 29 non-small cell lung carcinoma tumor samples (Study VEG105290). (A). Breast cancer. (B). Non-small cell lung carcinoma.

(Table 2, Figures $2 \mathrm{C}$ and $3 \mathrm{C}$ ). There was too little $\mathrm{MPL}$ mRNA expression in the tumor samples to determine any relationship between $M P L$ expression levels and stage of cancer in these breast, lung, or ovarian samples (Figure 3).
TPO-R protein expression by IHC

Immunohistochemical analysis examining multiple fields of FFPE samples of breast, lung, and ovarian patient tissue stained with the anti-TPO-R antibody (CD110) 
Table 2 Expression of detectable levels (abundance $\geq 50$ ) of MPL, EPOR, ERBB2, and IGF1R mRNA in normal tissue and tumor samples by qRT-PCR

\begin{tabular}{|c|c|c|c|c|c|c|}
\hline & $\begin{array}{c}\text { Breast normal } \\
\mathrm{N}=7 \mathrm{n}(\%)\end{array}$ & $\begin{array}{l}\text { Breast tumor } \\
\mathrm{N}=40 \mathrm{n}(\%)\end{array}$ & $\begin{array}{l}\text { Lung normal } \\
\mathrm{N}=8 \mathrm{n}(\%)\end{array}$ & $\begin{array}{l}\text { Lung tumor } \\
\mathrm{N}=40 \mathrm{n}(\%)\end{array}$ & $\begin{array}{c}\text { Ovarian normal } \\
\mathrm{N}=7 \mathrm{n}(\%)\end{array}$ & $\begin{array}{c}\text { Ovarian tumor } \\
\mathrm{N}=41 \mathrm{n}(\%)\end{array}$ \\
\hline$M P L$ & $1(14)$ & $1(3)$ & $1(13)$ & $1(3)$ & $3(43)$ & $3(7)$ \\
\hline$E P O R$ & $7(100)$ & $32(80)$ & $8(100)$ & $28(70)$ & $7(100)$ & $41(100)$ \\
\hline ERBB2 & $4(57)$ & $33(83)$ & $8(100)$ & $22(55)$ & $7(100)$ & $39(95)$ \\
\hline IGFIR & 2 (29) & 15 (38) & $1(13)$ & $2(5)$ & $0(0)$ & $7(17)$ \\
\hline
\end{tabular}

Quantitative reverse transcription-polymerase chain reaction was used to measure abundance of these genes. Data are represented as number of samples with detectable expression and percent of the samples in parenthesis.

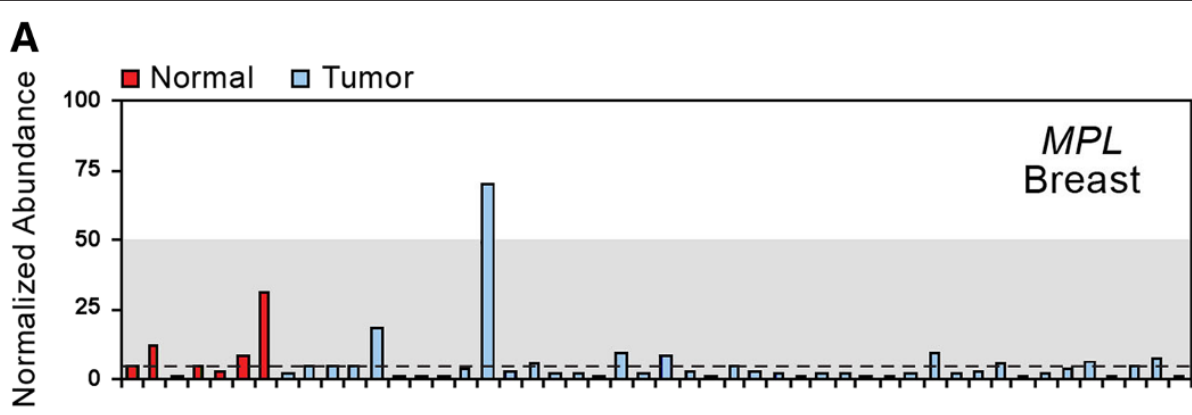

Gray box is the limit of detection.

- - - Mean abundance of normal tissue

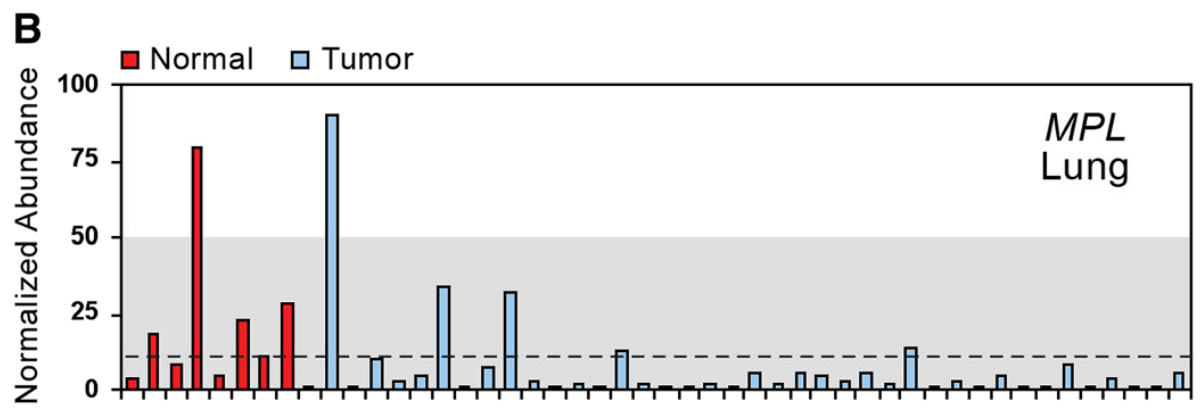

Gray box is the limit of detection.

C - - - Mean abundance of normal tissue

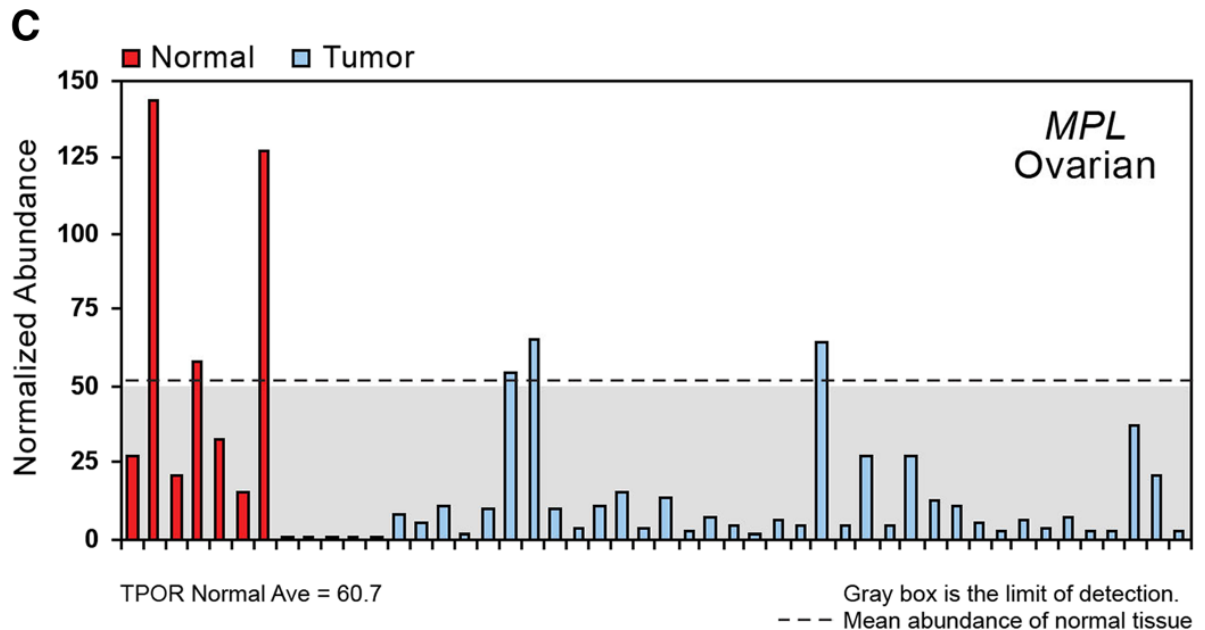

Figure 2 Relative abundance of MPL mRNA expression determined by qRT-PCR in normal (red bars) and tumor (blue bars) samples. Abundance is normalized to GAPDH, $\beta$-actin, and cyclophilin. The dashed line represents the mean of the normal samples. The gray box represents relative abundance below the level of accurate detection (abundance $<50$ ). (A). Breast. (B). Lung. (C). Ovarian. 


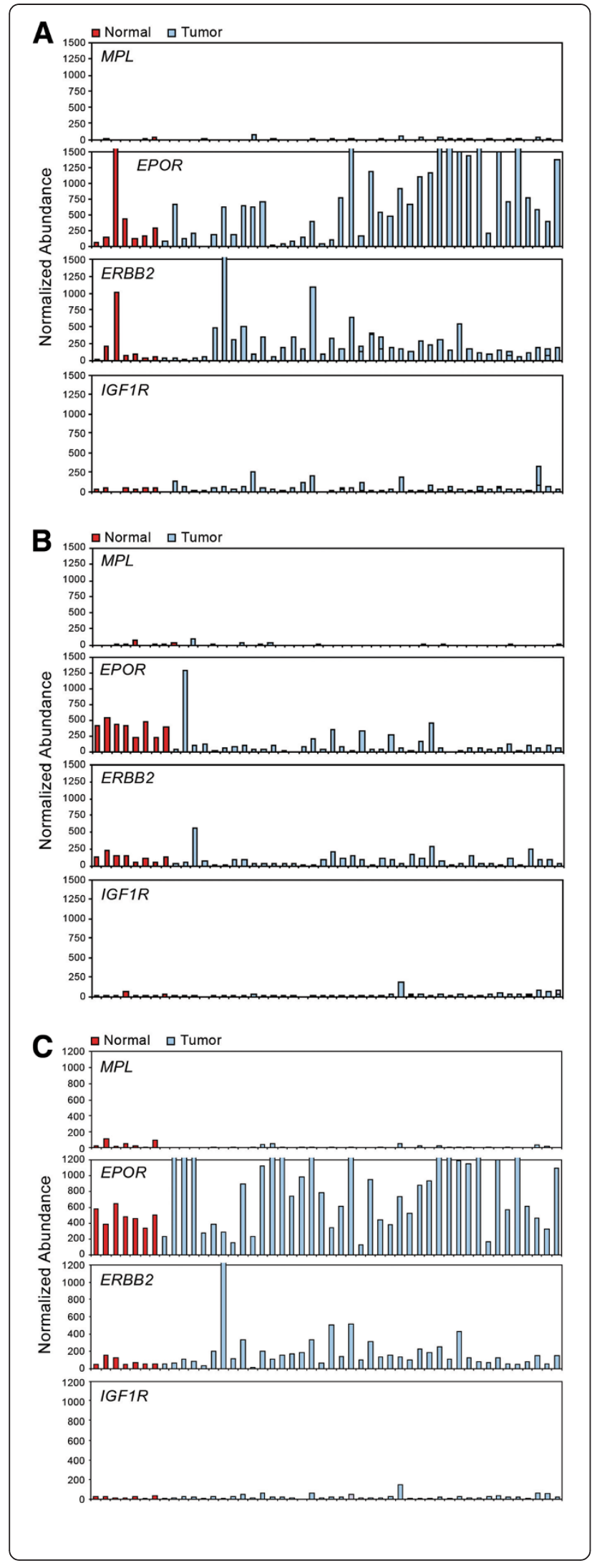

Figure 3 Relative abundance of MPL, EPOR, ERBB2, and IGF1R mRNA expression determined by qRT-PCR in normal and tumor samples. Abundance is normalized to GAPDH, $\beta$-actin, and cyclophilin. Red bars are normal samples, blue bars are tumor samples. Relative abundance below 50 is below the level of detection. (A). Breast tumor taqman. (B). Lung tumor taqman. (C). Ovarian tumor taqman.

demonstrated little or no specific signal. One breast tumor section showed a $1+$ signal in one of infiltrating inflammatory cell, but no staining of tumor cells was noted. (Figure 4 and Additional file 2: Table S2). As expected, the positive controls of normal bone marrow megakaryocytes and the $\mathrm{N} 2 \mathrm{C}$-Tpo cell line (Figure 4 bottom panels) demonstrated robust specific staining with the antibody.

\section{Cell line proliferation assays}

Given that the expression of mRNA does not always reflect the expression of protein, several breast, lung, and ovarian cancer cell lines were chosen to assess the effects of eltrombopag on proliferation using the Cell Titer Glo assay. Three different breast cancer cell lines MCF-7, BT474, and HCC1937 were incubated with eltrombopag for 72 hours to determine whether this compound stimulated proliferation of breast cancer cells. The MCF-7 cell line data are shown as a representative experiment in Figure 5A. No increase in cell number was observed in the 3 breast cancer cell lines with eltrombopag $(0.1-100 \mu \mathrm{g} / \mathrm{mL})$; in fact, all of them showed a decrease in cell number at eltrombopag concentrations $>4 \mu \mathrm{g} / \mathrm{mL}$. Recombinant TPO did not increase or decrease proliferation of any of these breast cancer cell lines (data not shown). Table 3 shows the $\mathrm{IC}_{50}$ of eltrombopag on these cell lines: $19.0 \mu \mathrm{g} / \mathrm{mL}$ for MCF-7; $9.6 \mu \mathrm{g} / \mathrm{mL}$ for BT474; and $10.7 \mu \mathrm{g} / \mathrm{mL}$ for HCC1937.

Four lung carcinoma cell lines were studied to determine whether eltrombopag stimulated proliferation including 3 NSCLC (A549, from an alveolar cell carcinoma; NCI-H226, from a squamous cell carcinoma; and NCI-H460, from a large cell carcinoma) and a small cell lung carcinoma cell line, NCI-H510. There was no increase in cell number over 72 hours of treatment with eltrombopag at concentrations from $0.1 \mu \mathrm{g} / \mathrm{mL}$ to $40 \mu \mathrm{g} / \mathrm{mL}$ in any of the 4 lung carcinoma cell lines. The response of NCI-H226 to eltrombopag is shown in Figure 5B. All cell lines showed a decrease in cell number at higher concentrations of eltrombopag $(>4 \mu \mathrm{g} / \mathrm{mL})$. Recombinant TPO did not affect the proliferation, either positively or negatively, of any of these cell lines (data not shown). As shown in Table 3, the $\mathrm{IC}_{50}$ of eltrombopag on these cell lines was $9.0 \mu \mathrm{g} / \mathrm{mL}$ for A549; $3.7 \mu \mathrm{g} / \mathrm{mL}$ 


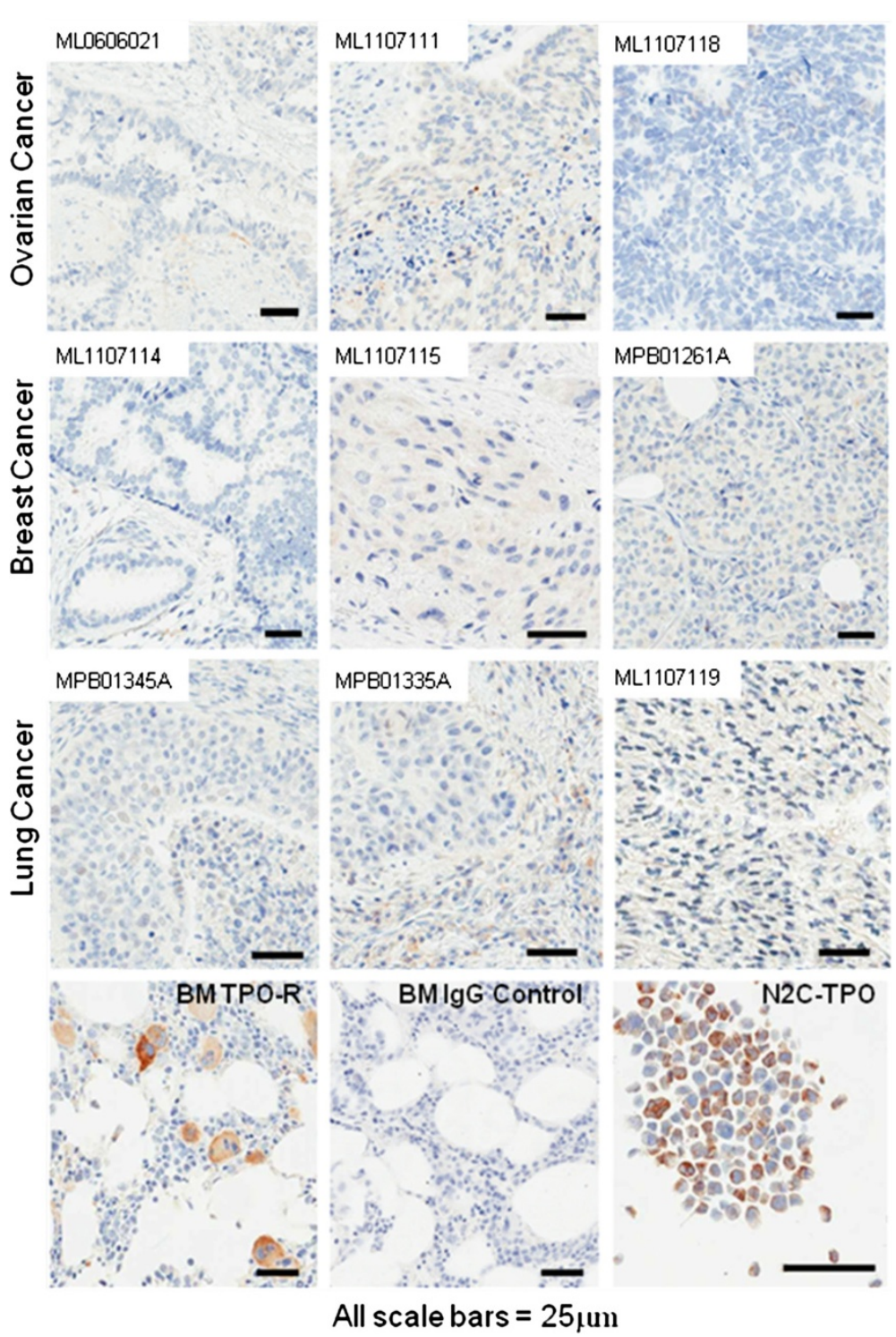

Figure 4 Immunohistochemistry staining of breast, lung, and ovarian tumor samples for TPO-R. Bottom panel: specific staining of megakaryocytes in normal bone marrow with anti-CD110 (TPO-R) versus the isotype control (lgG) and staining of positive control N2C-Tpo cell line.

for NCI-H226; $8.1 \mu \mathrm{g} / \mathrm{mL}$ for NCI-H460; and $10.3 \mu \mathrm{g} / \mathrm{mL}$ for NCI-H510.

None of the ovarian carcinoma cell lines (OVCAR3, OVCAR4, and SKOV-3) demonstrated increased proliferation in response to $0.1 \mu \mathrm{g} / \mathrm{mL}$ to $100 \mu \mathrm{g} / \mathrm{mL}$ eltrombopag treatment over 72 hours. For all 3 cell lines, cell number decreased at eltrombopag concentrations $>4 \mu \mathrm{g} / \mathrm{mL}$. A representative experiment demonstrating the response of OVCAR3 cells is shown in Figure 5C. Recombinant TPO had no positive or negative proliferative effect on these cell lines (data not shown). As shown in Table 3, the $\mathrm{IC}_{50}$ of eltrombopag on these cell lines was $4.8 \mu \mathrm{g} / \mathrm{mL}$ for OVCAR3, $11.0 \mu \mathrm{g} / \mathrm{mL}$ for OVCAR4, and $49.7 \mu \mathrm{g} / \mathrm{mL}$ for SKOV-3.

\section{Cell line TPO-R protein expression}

We had previously noted that NCI-H510, the cell line derived from small cell lung carcinoma, expressed high levels of MPL mRNA by qRT-PCR [31]. We sought to determine whether mRNA expression correlated with TPO-R protein expression using Western blots of cell lysates of lung cancer cell lines treated with eltrombopag. In NCI-H510 cell lysates, no band corresponding to TPO-R protein was detected. Human platelets and the megakaryocytic cell lines N2C-Tpo and HEL92.1.7 had high levels of MPL mRNA and TPO-R protein (Figure 6). NCI-H226 and NCI-H460 cell lines did not express detectable MPL mRNA by qRT-PCR, nor did they demonstrate TPO-R protein on Western blots. Western blots 


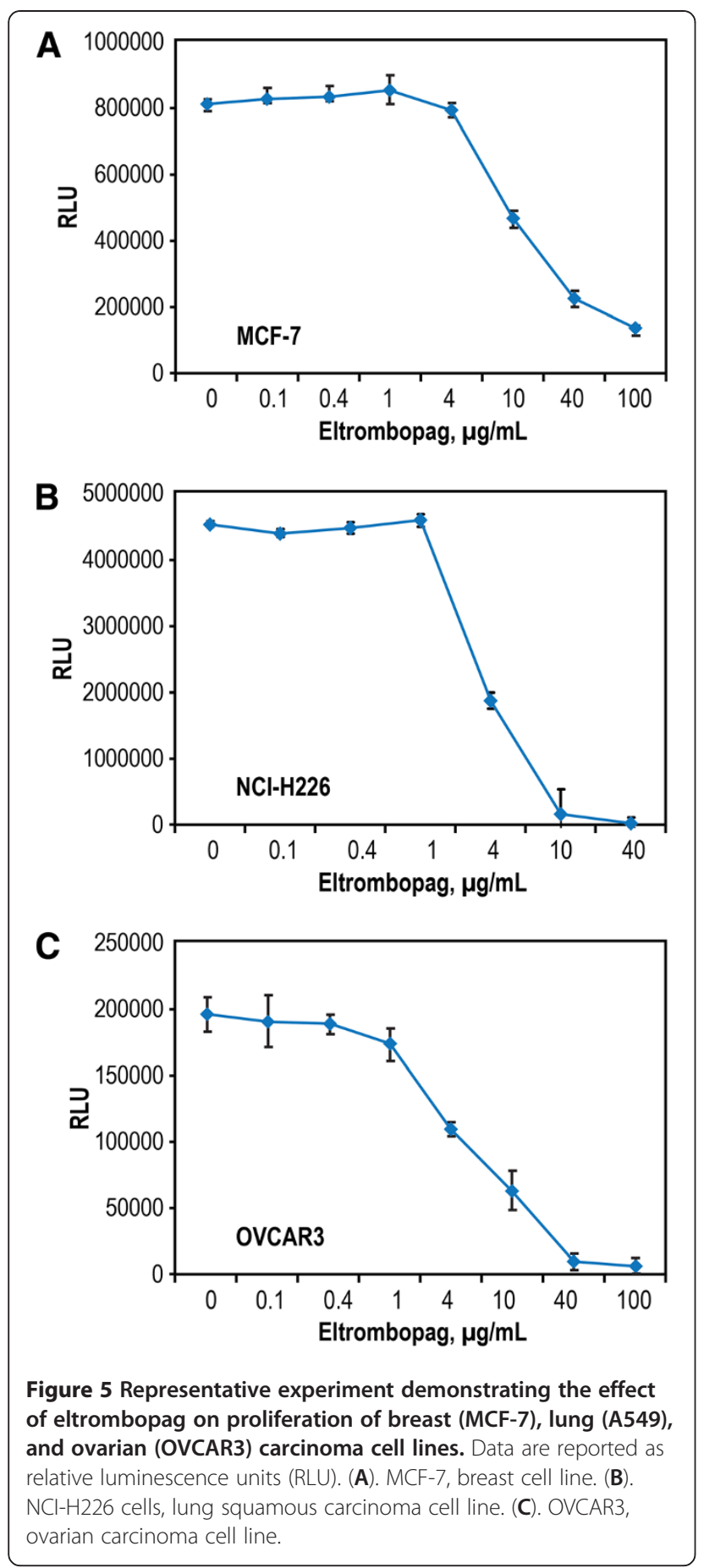

reveal a band corresponding to a protein smaller than TPO-R in NCI-510 and NCI-H226 cell lysates that is also present in N2C-Tpo and HEL92.1.7 lysates, but the identity of this band is unknown.

Thrombocytopenia is commonly observed during treatment with a number of chemotherapy regimens approved or in development for the treatment of breast,
Table $3 \mathbf{I C}_{50}$ of proliferation of eltrombopag on breast, lung, and ovarian tumor cell lines

\begin{tabular}{lcc}
\hline Cell line & Tumor type & $\mathbf{I C}_{\mathbf{5 0}}(\boldsymbol{\mu \mathbf { g } / \mathbf { m L } )}$ \\
\hline MCF-7 & Breast carcinoma & 19.0 \\
\hline BT474 & Breast carcinoma & 9.6 \\
\hline HCC1937 & Breast carcinoma & 10.7 \\
\hline A549 & Lung alveolar cell carcinoma & 9.0 \\
\hline NCI-H226 & Lung squamous cell carcinoma & 3.7 \\
\hline NCI-H460 & Large cell lung carcinoma & 8.1 \\
\hline NCI-H510 & Small cell lung carcinoma & 10.3 \\
\hline OVCAR3 & Ovarian adenocarcinoma & 4.8 \\
\hline OVCAR4 & Ovarian carcinoma & 11.0 \\
\hline SKOV-3 & Ovarian adenocarcinoma & 49.7 \\
\hline
\end{tabular}

lung, and ovarian cancers [8,32-36]. Identification and characterization of novel, safe, and effective thrombopoietic agents to ameliorate thrombocytopenia remains an intense area of research [20]. Eltrombopag interacts with TPO-R, stimulates megakaryopoiesis, and promotes platelet production and maturation. Although $M P L$ is expressed on megakaryocytes and megakaryocyte precursors [15-18], little quantitative data are available on $M P L$ expression in other tissues.

In this study, $M P L$ expression was compared with expression of other genes (EPOR, ERBB2, and IGF1R), which have been widely reported [37-42]. Our analyses showed that MPL was not commonly expressed at detectable levels in tumor samples as measured by qRTPCR. Using microarray analyses, MPL expression was lower than other cell surface receptors. Even when protein is expressed, it may not be folded properly to allow ligand interactions. For example, although MPL is expressed on leukemic blasts from patients with AML [23], no proliferation in response to eltrombopag in bone marrow mononuclear cells from patients with AML or MDS has been observed [26]. Nor did eltrombopag stimulate proliferation in a variety of non-megakaryocytic leukemia and lymphoma cell lines; decreased proliferation was observed at physiologically achievable eltrombopag concentrations $(\geq 4 \mu \mathrm{g} / \mathrm{mL})$ [19]. The observed median Cmax for eltrombopag in patients with ITP is $11.4 \mu \mathrm{g} / \mathrm{mL}$ at the 75-mg dose [19], while in patients with chemotherapyinduced thrombocytopenia, the observed median Cmax

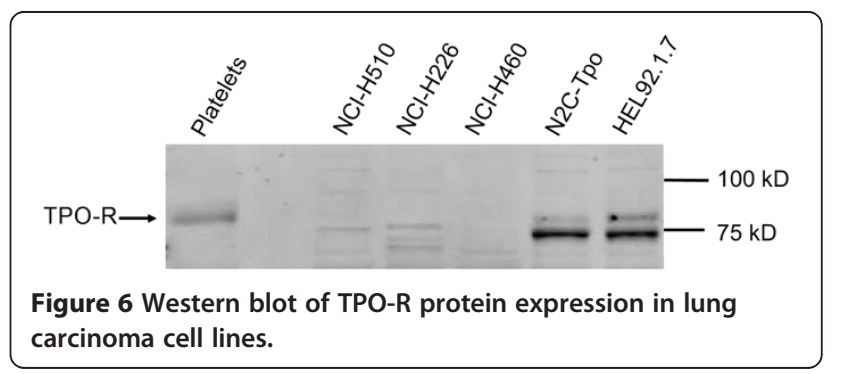


at the 75-mg dose (based on sparse data) is approximately $9.90 \mu \mathrm{g} / \mathrm{mL}$ (unpublished data). Therefore, the dose at which tumor cell line growth declines is in a physiologically achievable range. Further studies are needed to determine whether eltrombopag affects tumor growth in vivo.

\section{Conclusions}

Eltrombopag did not stimulate growth of breast, lung, or ovarian cancer cell lines at doses likely to exert action on megakaryocytes and megakaryocyte precursors. Tumor samples of these types had very little, or no, $M P L$ mRNA or TPO-R protein expression as determined by qRT-PCR or IHC, respectively.

\section{Additional files}

Additional file 1: Table S1. Sequences of primers and probes utilized in $q R T-P C R$ analyses. qRT-PCR, quantitative reverse transcriptionpolymerase chain reaction.

Additional file 2: Table S2. Pathologists review of

immunohistochemistry slides.

\section{Abbreviations}

ACTB: $\beta$-actin; AEs: Adverse events; AML: Acute myeloid leukemia; Bp: Base pair; CT: Cycle time; FCS: Fetal calf serum; FFPE: Formalin-fixed parafin embedded; FISH: Fluorescence in situ hybridization; GAPDH: Glyceraldehyde3-phosphate dehydrogenase; IHC: Immunohistochemistry; IMDM: Iscove's Modified Dulbecco's Medium; IRB: Institutional Review Board; ITP: Chronic immune thrombocytopenia; MDS: Myelodysplastic syndromes; NSCLC Non-small cell lung cancer; PPIA: Cyclophilin A; qRT-PCR: Quantitative reverse transcription-polymerase chain reaction; rhTPO: Recombinant human TPO; RLU: Relative luminescence units; RMA: Robust microchip analysis; RT-PCR: Reverse transcription-polymerase chain reaction;

TPO: Thrombopoietin; TPO-R: Thrombopoietin receptor.

\section{Competing interests}

CLEM is employed by GlaxoSmithKline (GSK), holds stock, and receives research funding. KP is a former employee of GSK, held stock, and received research funding. JK is employed by GSK. DJF, LO, AMM, YL, YMK, and CM are employed by GSK and hold stock.

\section{Authors' contributions}

CLEM contributed to the conception and design of the experiments, analyzed and interpreted data, drafted and critically reviewed the manuscript. KP carried out gene profiling and cell proliferation assays. JK performed qRT-PCR and cell proliferation assays. DJF participated in IHC data acquisition, and analysis and interpretation. LO participated in data acquisition and manuscript revisions. AMM conducted research that contributed to results and helped in writing and editing the manuscript. $Y L$ participated in data acquisition and data analysis and interpretation. YMK participated in the interpretation of data and critical review of the manuscript. CM contributed to the conception and design of the experiments, interpreted the data, and drafted and critically reviewed the manuscript. All authors read and approved the final manuscript.

\section{Acknowledgements}

Funding for this study was provided by GlaxoSmithKline (GSK). All listed authors meet the criteria for authorship set forth by the International Committee for Medical Journal Editors. The authors wish to acknowledge the following individuals for their contributions and critical review during the development of this manuscript on behalf of GSK: Rachel Brody and AOI Communications, L.P., for medical writing and editorial assistance, and Kimberly Marino and Rosanna Tedesco of GSK for critical review.

\section{Author details}

${ }^{1}$ GlaxoSmithKline, 1250 South Collegeville Rd, Collegeville, PA 19426, USA.

${ }^{2}$ GlaxoSmithKline, Stockley Park, Uxbridge Middlesex UB11 1BT, UK.

Received: 17 May 2012 Accepted: 9 August 2012

Published: 11 September 2012

\section{References}

1. Jemal A, Siegel R, Ward E, Hao Y, Xu J, Murray T, Thun MJ: Cancer Statistics, 2008. CA Cancer J Clin 2008, 58:71-96.

2. Carlson RW, Allred DC, Anderson BO, Burstein HJ, Carter WB, Edge SB, Erban JK, Farrar WB, Goldstein LJ, Gradishar WJ: National Comprehensive Cancer Network. NCCN Clinical Practice Guidelines in Oncology: Breast Cancer. 2012. V.2. http://www.nccn.org.

3. National Cancer Institute: Breast Cancer Treatment (PDQ). http://www.cancer. gov/cancertopics/pdq/treatment/breast/healthprofessional/.

4. Morgan RJ Jr, Alvarez R, Armstrong DK, Boston B, Burger R, Chen L, Copeland L, Crispens MA, Fowler J: National Comprehensive Cancer Network. NCCN Clinical Practice Guidelines in Oncology: Ovarian Cancer Including Fallopian Tube Cancer and Primary Peritoneal Cancer. 2012:V.3. http://www.nccn.org.

5. National Cancer Institute: Ovarian Epithelial Cancer Treatment (PDQ). http://www.cancer.gov/cancertopics/pdq/treatment/ovarianepithelial/ healthprofessional/.

6. Ettinger DS, Akerley W, Bepler G, Blum MG, Chang A, Cheney RT, Chirieac LR, D'Amico TA, Demmy TL, Feigenberg SJ, Govindan R: National Comprehensive Cancer Network. NCCN Clinical Practice Guidelines in Oncology: Non-Small Cell Lung Cancer. 2012: V2. http://www.ncen.org.

7. National Cancer Institute: Non-Small Cell Lung Cancer Treatment (PDQ) http://www.cancer.gov/cancertopics/pdq/treatment/non-small-cell-lung/ healthprofessional/.

8. Gronberg BH, Bremnes RM, Flotten O, Amundsen T, Brunsvig PF, Hjelde HH, Kaasa S, von Plessen C, Stornes F, Tollali T, et al: Phase III study by the Norwegian lung cancer study group: pemetrexed plus carboplatin compared with gemcitabine plus carboplatin as first-line chemotherapy in advanced non-small-cell lung cancer. J Clin Oncol 2009, 27:3217-3224.

9. Elting LS, Rubenstein EB, Martin CG, Kurtin D, Rodriguez S, Laiho E, Kanesan K, Cantor SB, Benjamin RS: Incidence, cost, and outcomes of bleeding and chemotherapy dose modification among solid tumor patients with chemotherapy-induced thrombocytopenia. J Clin Oncol 2001, 19:1137-1146.

10. Lyman GH: Guidelines of the National Comprehensive Cancer Network on the use of myeloid growth factors with cancer chemotherapy: a review of the evidence. J Natl Compr Canc Netw 2005, 3:557-571.

11. Mughal TI: Current and future use of hematopoietic growth factors in cancer medicine. Hematol Oncol 2004, 22:121-134.

12. Beinert T: Role of supportive care in the treatment of NSCLC: supportive care for myelotoxicity. Lung Cancer 2002, 38(Suppl 3):S79-S80.

13. Newland AM, Black CD: Tumor progression associated with erythropoiesis-stimulating agents. Ann Pharmacother 2008, 42:1865-1870

14. Merchionne F, Dammacco F: Biological functions and therapeutic use of erythropoiesis-stimulating agents: perplexities and perspectives. $\mathrm{Br} J$ Haematol 2009, 146:127-141.

15. de Sauvage FJ, Carver-Moore K, Luoh SM, Ryan A, Dowd M, Eaton DL, Moore MW: Physiological regulation of early and late stages of megakaryocytopoiesis by thrombopoietin. J Exp Med 1996, 183:651-656.

16. Kaushansky K, Drachman JG: The molecular and cellular biology of thrombopoietin: the primary regulator of platelet production. Oncogene 2002, 21:3359-3367.

17. Deutsch VR, Tomer A: Megakaryocyte development and platelet production. Br J Haematol 2006, 134:453-466.

18. Kaushansky K, Broudy VC, Lin N, Jorgensen MJ, McCarty J, Fox N, ZuckerFranklin D, Lofton-Day C: Thrombopoietin, the MPL ligand, is essential for full megakaryocyte development. Proc Natl Acad Sci USA 1995, 92:3234-3238.

19. Peeters K, Stassen JM, Collen D, Van Geet C, Freson K: Emerging treatments for thrombocytopenia: increasing platelet production. Drug Discov Today 2008, 13:798-806. 
20. Erickson-Miller CL, Delorme E, Tian SS, Hopson CB, Landis AJ, Valoret El, Sellers TS, Rosen J, Miller SG, Luengo Jl, et al: Preclinical activity of eltrombopag (SB-497115), an oral, nonpeptide thrombopoietin receptor agonist. Stem Cells 2009, 27:424-430.

21. Erhardt JA, Erickson-Miller CL, Aivado M, Abboud M, Pillarisetti K, Toomey JR: Comparative analyses of the small molecule thrombopoietin receptor agonist eltrombopag and thrombopoietin on in vitro platelet function. Exp Hematol 2009, 37(9):1030-1037.

22. Wetzler M, Bernstein SH, Baumann H, Fries KM, Stewart C, Blumenson L, Baer MR, Herzig GP, Bloomfield CD, Slack JL: Expression and function of the megakaryocyte growth and development factor receptor in acute myeloid leukemia blasts. Leuk Lymphoma 1998, 30:415-431.

23. Motoji T, Takanashi M, Motomura S, Wang WH, Shiozaki H, Aoyama M, Mizoguchi H: Growth stimulatory effect of thrombopoietin on the blast cells of acute myelogenous leukaemia. Br J Haematol 1996, 94:513-516.

24. Murayama T, Imoto S, Natazuka T, Chihara K, Matsui T: Proliferative reaction of myelogenous leukemia cells with cytokines G-CSF, GM-CSF, M-CSF, SCF and TPO. Leuk Res 1998, 22:557-560.

25. Will B, Kawahara M, Luciano JP, Bruns I, Parekh S, Erickson-Miller CL, Aivado MA, Verma A, Steidl U: Effect of the non-peptide thrombopoietin receptor agonist eltrombopag on bone marrow cells from patients with acute myeloid leukemia and myelodysplastic syndrome. Blood 2009, 114:3899-3908.

26. Erickson-Miller CL, Kirchner J, Aivado M, May R, Payne P, Chadderton A Reduced proliferation of non-megakaryocytic acute myelogenous leukemia and other leukemia and lymphoma cell lines in response to eltrombopag. Leuk Res 2010, 34:1224-1231.

27. Mavroudi I, Pyrovolaki K, Pavlaki K, Kozana A, Psyllaki M, Kalpadakis C, Pontikoglou C, Papadaki HA: Effect of the nonpeptide thrombopoietin receptor agonist eltrombopag on megakaryopoiesis of patients with lower risk myelodysplastic syndrome. Leuk Res 2011, 35:23-328.

28. Geyer CE, Forster J, Lindquist D, Chan S, Romieu CG, Pienkowski T, Jagiello-Gruszfeld A, Crown J, Chan A, Kaufman B, et al: Lapatinib plus capecitabine for HER2-positive advanced breast cancer. N Engl J Med 2006, 355:2733-2743.

29. Sherrill B, Amonkar MM, Stein S, Walker M, Geyer C, Cameron D: Q-TWiST analysis of lapatinib combined with capecitabine for the treatment of metastatic breast cancer. Br J Cancer 2008, 99:711-715.

30. Irizarry RA, Hobbs B, Collin F, Beazer-Barclay YD, Antonellis KJ, Scherf U, Speed TP: Exploration, normalization, and summaries of high density oligonucleotide array probe level data. Biostatistics 2003, 4:249-264.

31. Erickson-Miller CL, Chadderton A, Gibbard A, Kirchner J, Pillarisetti K, Baker K, Pandite L, El-Hariry I, Mostafa Kamel Y, Liu Y, et al: Thrombopoietin receptor levels in tumor cell lines and primary tumors. J Oncol 20102010. doi:10.1155/2010/135354. Article ID 135354.

32. Davies AM, Chansky K, Lara PN Jr, Gumerlock PH, Crowley J, Albain KS, Vogel SJ, Gandara DR: Bortezomib plus gemcitabine/carboplatin as first-line treatment of advanced non-small cell lung cancer: a phase II Southwest Oncology Group Study (S0339). J Thorac Oncol 2009, 4:87-92.

33. Smith JW 2nd, Mclntyre K, Acevedo PV, Encarnacion CA, Tedesco KL, Wang Y, Asmar L, O'Shaughnessy JA: Results of a phase II open-label, nonrandomized trial of oral satraplatin in patients with metastatic breast cancer. Breast Cancer Res Treat 2009, 118:361-367.

34. Chew HK, Doroshow JH, Frankel P, Margolin KA, Somlo G, Lenz HJ, Gordon M, Zhang W, Yang D, Russell C, et al: Phase II studies of gemcitabine and cisplatin in heavily and minimally pretreated metastatic breast cancer. J Clin Oncol 2009, 27:2163-2169.

35. Dasanu CA, Herzog TJ, Alexandrescu DT: Carboplatin-gemcitabine in the therapy of advanced ovarian cancer: dose reduction consideration. J Oncol Pharm Pract 2010, 16:63-66.

36. Kang H, Kim TJ, Lee YY, Choi CH, Lee JW, Bae DS, Kim BG: Topotecan combined with carboplatin in recurrent epithelial ovarian cancer: results of a single-institutional phase II study. Gynecol Oncol 2009, 114:210-214.

37. Tovari J, Pirker R, Timar J, Ostoros G, Kovacs G, Dome B: Erythropoietin in cancer: an update. Curr Mol Med 2008, 8:481-491.

38. Arcasoy MO: Erythropoiesis-stimulating agent use in cancer: preclinical and clinical perspectives. Clin Cancer Res 2008, 14:4685-4690.

39. Sinclair AM, Todd MD, Forsythe K, Knox SJ, Elliott S, Begley CG: Expression and function of erythropoietin receptors in tumors: implications for the use of erythropoiesis-stimulating agents in cancer patients. Cancer 2007, 110:477-488.
40. Werner $H$, Bruchim I: The insulin-like growth factor-I receptor as an oncogene. Arch Physiol Biochem 2009, 115:58-71.

41. Sotiriou C, Pusztai L: Gene-expression signatures in breast cancer. N Engl J Med 2009, 360:790-800.

42. Samani AA, Yakar S, LeRoith D, Brodt P: The role of the IGF system in cancer growth and metastasis: overview and recent insights. Endocr Rev 2007, 28:20-47.

doi:10.1186/1471-2407-12-405

Cite this article as: Erickson-Miller et al:: Low or undetectable TPO receptor expression in malignant tissue and cell lines derived from breast, lung, and ovarian tumors. BMC Cancer 2012 12:405.

\section{Submit your next manuscript to BioMed Central and take full advantage of:}

- Convenient online submission

- Thorough peer review

- No space constraints or color figure charges

- Immediate publication on acceptance

- Inclusion in PubMed, CAS, Scopus and Google Scholar

- Research which is freely available for redistribution

Submit your manuscript at www.biomedcentral.com/submit
C) Biomed Central 